\title{
BLOOD CYTOKINE RESPONSE OF LOW-DOSE MOLGRAMOSTIM (rhGM-CSF)-TREATED PATIENTS
}

\author{
Thomas Hartung, ${ }^{*}$ Sonja von Aulock, ${ }^{1}$ Marcus Freitag, ${ }^{2}$ Stefan Höxtermann, ${ }^{2}$ \\ Markus Stücker, ${ }^{2}$ Klaus Hoffmann, ${ }^{2}$ Peter Altmeyer, ${ }^{2}$ Andrea Kottke, ${ }^{3}$ \\ Albrecht Wendel ${ }^{1}$
}

\begin{abstract}
We examined leukocyte counts and ex vivo cytokine response of whole blood to lipopolysaccharide (LPS) or lipoteichoic acid (LTA) in patients under low-dose molgramostim therapy. Patients were injected subcutaneously daily for ten days with $1 \mu \mathrm{g} / \mathrm{kg}(n=9)$ or $2 \mu \mathrm{g} / \mathrm{kg}(n=14)$ molgramostim. Leukocytosis was observed in all patients, but only the eosinophil fraction was significantly increased in relation to other leukocyte populations. Ex vivo IFN- $\gamma$ release was decreased and IL-10 and IL-1ra secretion were increased in response to LPS or LTA. Thus, in non-neutropenic patients, leukocytosis can already be initiated by low doses of molgramostim. The ex vivo cytokine data suggest that these doses prime blood towards a systemic anti-inflammatory response.
\end{abstract}

The pluripotent haematopoietic growth factor granulocyte-macrophage colony-stimulating factor (GM-CSF) regulates proliferation, differentiation and mature functions of granulocytes and monocytes/ macrophages. Recombinant human GM-CSF (rhGMCSF) shortens idiopathic leukopenias and reduces risk of infection. ${ }^{1}$ This protection may also result from the stimulation of mature immune cell functions, an effect which, if not tightly controlled, can exacerbate the inflammatory reaction which may lead to tissue damage and septic shock. Various in vitro, ex vivo and in vivo experiments have shown that rhGM-CSF potentiates the release of the pro-inflammatory cytokines TNF- $\alpha$ and IL-1 in response to LPS. ${ }^{1-3}$

Though administration of rhGM-CSF $\left(750 \mu \mathrm{g} / \mathrm{m}^{2}\right.$ per day i.v.) to sarcoma patients with neutropenia increased ex vivo LPS-stimulated TNF- $\alpha$ and IL-1 $\beta$

From the ${ }^{1}$ Department of Biochemical Pharmacology, University of Konstanz, Konstanz; ${ }^{2}$ Department of Dermatology, University of Bochum, Bochum; ${ }^{3}$ Essex Pharma GmbH, Munich, Germany Correspondence to: Thomas Hartung, University of Konstanz, Biochemical Pharmacology, 78457 Konstanz, Germany. E-mail: Thomas.Hartung@,uni-konstanz.de

KEY WORDS: blood/cytokines/growth factors/human/inflammation release by monocytes, this high dose administered daily for two weeks did not affect the spontaneous release of these cytokines. ${ }^{4}$ In another study in cancer patients, one single dose $(2.5,5$, or $10 \mu \mathrm{g} / \mathrm{kg})$ of rhGM-CSF resulted in a significant increase of plasma levels of the anti-inflammatory mediator IL-1 receptor antagonist (IL-1ra) and a trend towards increased levels of the chemokine IL- $8{ }^{5}$ These observations combined with the relatively low incidence of inflammatory side effects reported in the several hundred thousand patients already treated with rhGM-CSF, led to the hypothesis that lower doses of rhGM-CSF might suffice to initiate leukocytosis without exacerbating inflammation. In the context of a dose-finding study examining the potential of rhGM-CSF in wound healing, ${ }^{6}$ we tested this idea. Whole blood from rhGM-CSF treated patients was exposed to the bacterial components lipopolysaccharide (LPS) or lipoteichoic acid (LTA) ex vivo, so allowing the assessment of alterations of the humoral immune reaction without exposing patients to these stimuli. $^{7}$

\section{RESULTS}

\section{Tolerability}

In the group receiving $2 \mu \mathrm{g} / \mathrm{kg}$ - rhGM-CSF, 27 cases of side effects were recorded while there were only 


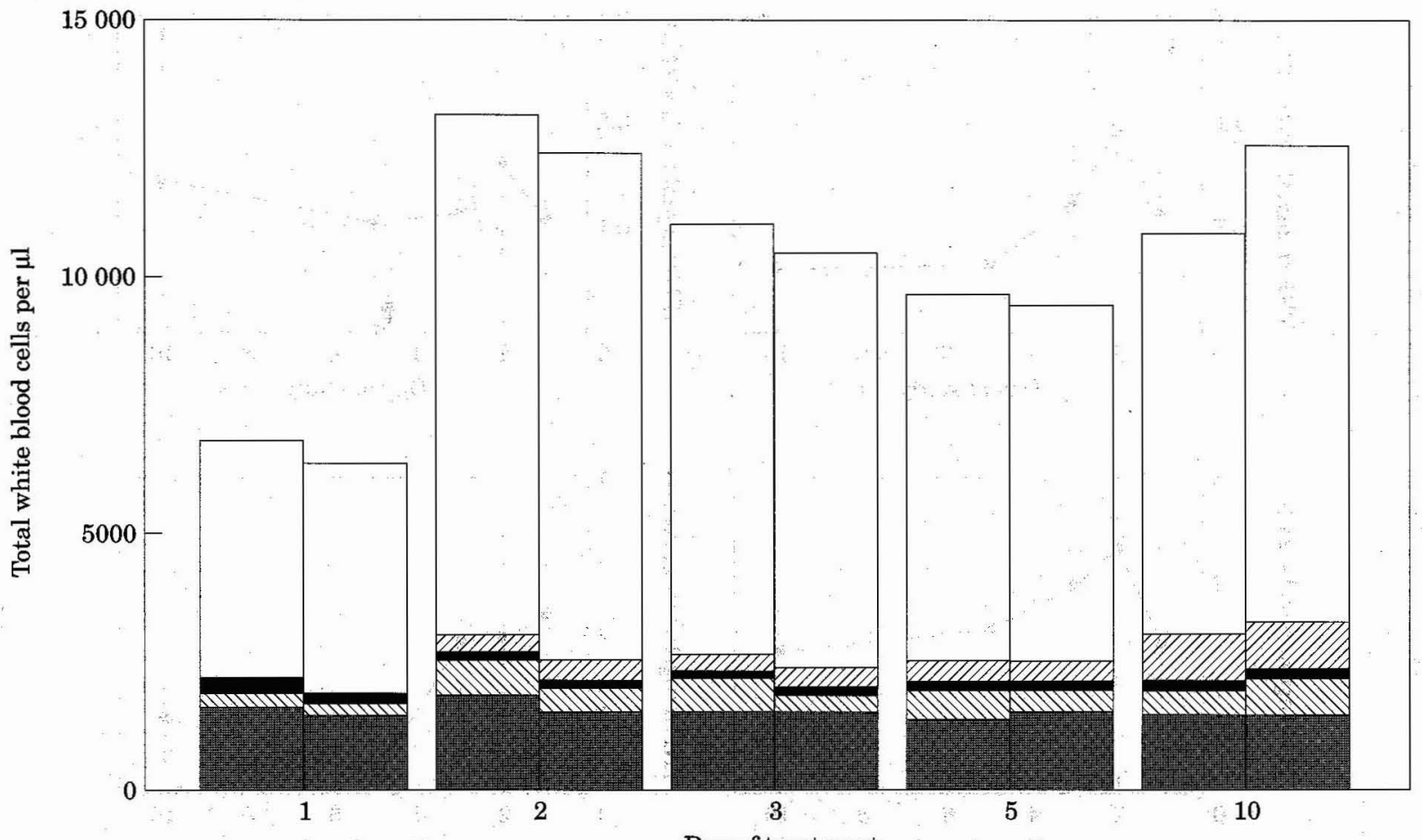

Figure 1. Leukocyte counts under molgramostim treatment.

Changes in leukocyte counts by daily subcutaneous injections of molgramostim in a group of nine patients receiving a dose of $1 \mu \mathrm{g} / \mathrm{kg}$ (left bars) and in a group of 14 patients receiving $2 \mu \mathrm{g} / \mathrm{kg}$ (right bars), respectively. Blood samples were taken shortly before the next injection. Neutrophils,

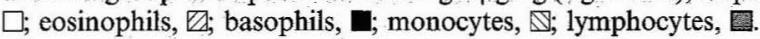

TABLE 1. Absolute and relative eosinophil numbers during the course of molgramostim treatment

\begin{tabular}{lccccc}
\hline & day 1 & day 2 & day 3 & day 5 & day 10 \\
\hline$n=$ & 23 & 14 & 15 & 11 & 7 \\
eosinophils/ $\mu \mathrm{l}$ & $101 \pm 18$ & $369 \pm 48$ & $352 \pm 42$ & $421 \pm 76$ & $890 \pm 140$ \\
eosinophil fraction & $1.6 \pm 0.2 \%$ & $3.0 \pm 0.4 \%$ & $3.4 \pm 0.3 \%$ & $4.6 \pm 0.6 \%$ & $7.8 \pm 1.1 \%$ \\
\hline
\end{tabular}

Responses of patients treated with either $1 \mu \mathrm{g} / \mathrm{kg}$ or $2 \mu \mathrm{g} / \mathrm{kg}$ molgramostim per day did not differ significantly, therefore the data from both groups were combined. Data are mean \pm SEM.

13 in the $1 \mu \mathrm{g} / \mathrm{kg}$ group. No severe adverse events occurred. ${ }^{6}$

\section{Leukocyte counts}

In both dosage groups, the leukocyte count doubled by day 2 and remained elevated above basal values (Fig. 1). These changes mainly reflected increases in neutrophil and monocyte counts. Also, the eosinophil count rose steadily, reaching nine-fold initial values on day 10 (Table 1 ).

\section{Cytokine release}

Spontaneous release of TNF- $\alpha$ and IL-8 increased slightly on day 2 (Fig. $2 \mathrm{~A}$ and $\mathrm{C}$ ), but was slightly decreased when calculated per monocyte (Fig. 2D). Spontaneous IFN- $\gamma$ release was unchanged (Fig. 2B).
In patients' blood stimulated with LPS, we observed an initial increase in TNF- $\alpha$ release followed by a decrease after prolonged treatment (Fig. 3A). Intracellular TNF- $\alpha$ measurements with fluorescencelabelled anti-TNF- $\alpha$ antibodies in LPS-stimulated blood detected only monocytes as producers of TNF- $\alpha$ (data not shown). So, we calculated the release of TNF- $\alpha$ per million monocytes and found this was unaltered throughout the study (Fig. 3B), indicating that the total increase in TNF- $\alpha$ production stemmed from normal, competent and not pre-activated cells. There was a trend towards a decrease in total IFN- $\gamma$ release (Fig. 3C) and the production of $I L-1 \beta$ (Fig. 3D) only increased after prolonged rhGM-CSF treatment, while IL-8 or IL-12 production were hardly affected (Fig. 3E and F). 

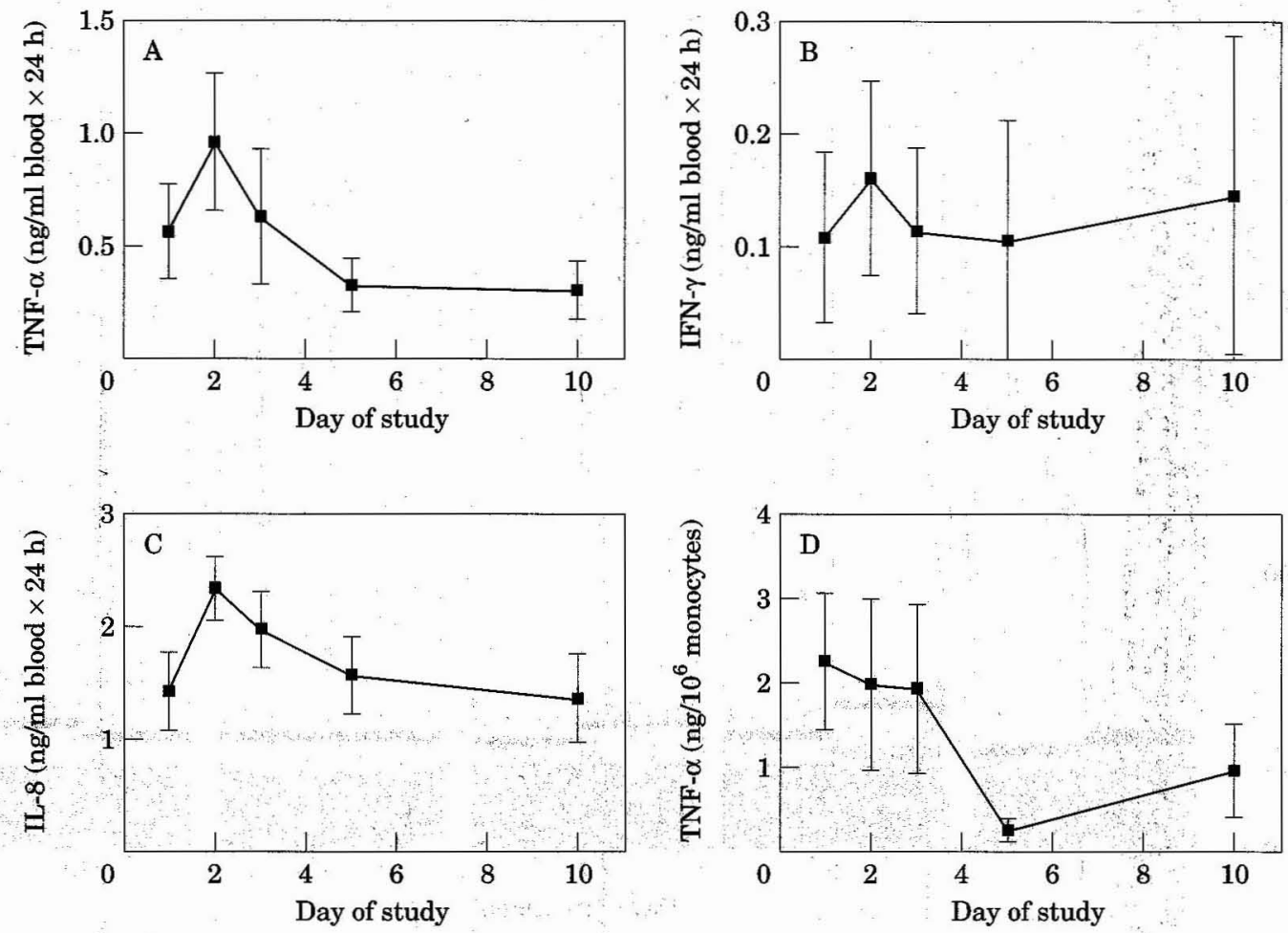

Figure 2. Spontaneous cytokine release.

Spontaneous release of cytokines by whole blood from patients treated with $1 \mu \mathrm{g} / \mathrm{kg}$ or $2 \mu \mathrm{g} / \mathrm{kg}$ molgramostim per day. The cytokine concentration was determined by ELISA after $24 \mathrm{~h}$ of incubation. The release of TNF- $\alpha$ was also related to monocytes in the incubation. A, TNF- $\alpha$; B, IFN- $\gamma$; C, IL-8; D, TNF- $\alpha$ per monocyte.

LPS-stimulated ex vivo release of IL-1ra (Fig. 4A) quadrupled by day 2 and remained elevated. G-CSF and IL-10 release (Fig. 4B and C) increased transiently, reflecting changes in monocyte counts. The secretion of IL-6 persisted significantly above basal levels (data not shown).

The lower dose of molgramostim produced a stronger trend toward an anti-inflammatory profile of cytokine release on stimulation: here, the concentration of IL-10 released was always greater and the amount of IFN- $\gamma$ was always less.

The cytokine response to LTA corresponded closely with that described for LPS. The amounts of TNF- $\alpha$, G-CSF and IL-10 released were similar with both stimuli, while less IFN- $\gamma$ and more IL-8 and IL-6 were induced by LTA.

\section{DISCUSSION}

Although the molgramostim doses used were well below the recommended dosage for cancer patients $(5-10 \mu \mathrm{g} / \mathrm{kg}$ per day), a substantial leukocytosis was recorded. The disproportionate increase of the eosinophil count may be undesirable: Accumulation of eosinophils and macrophages after adenoviral expression of GM-CSF in rat lung was associated with tissue injury and fibrosis. ${ }^{8}$ However, in a patient with T-lymphocytosis, granulocytopenia and severe perianal infection, eosinophilia initiated by rhGM-CSF treatment correlated with improvement of the perianal ulceration. ${ }^{9}$

Other studies on CSF treatment ${ }^{1}$ have meanwhile shown that the chosen limit of 15000 leukocytes per $\mu 1$ blood, was somewhat conservative. We also found that the new leukocytes were not pre-activated. One $\mu \mathrm{g}$ and $2 \mu \mathrm{g} / \mathrm{kg}$ molgramostim per day were equipotent in stimulating haematopoiesis while the $1 \mu \mathrm{g} / \mathrm{kg}$ group reported fewer side effects indicating that low doses of rhGM-CSF might be more tolerable in nonneutropenic patients while retaining desired effects.

The cytokine response pattern towards inflammatory stimuli offered unexpected results: low doses of molgramostim promoted an anti-inflammatory profile, priming immune cells to produce more IL-10, G-CSF and IL-1ra, while release of pro-inflammatory TNF- $\alpha$, IFN- and IL-1 $\beta$ was not affected or slightly decreased. The distinct increase in IL-6 release may be considered a protective reaction that is initiated sooner under molgramostim treatment. ${ }^{10}$ Notably, cytokine release on day 2 was not different in patients who dropped out of or who completed treatment.

GM-CSF was previously classed a proinflammatory cytokine. Now it appears that the 

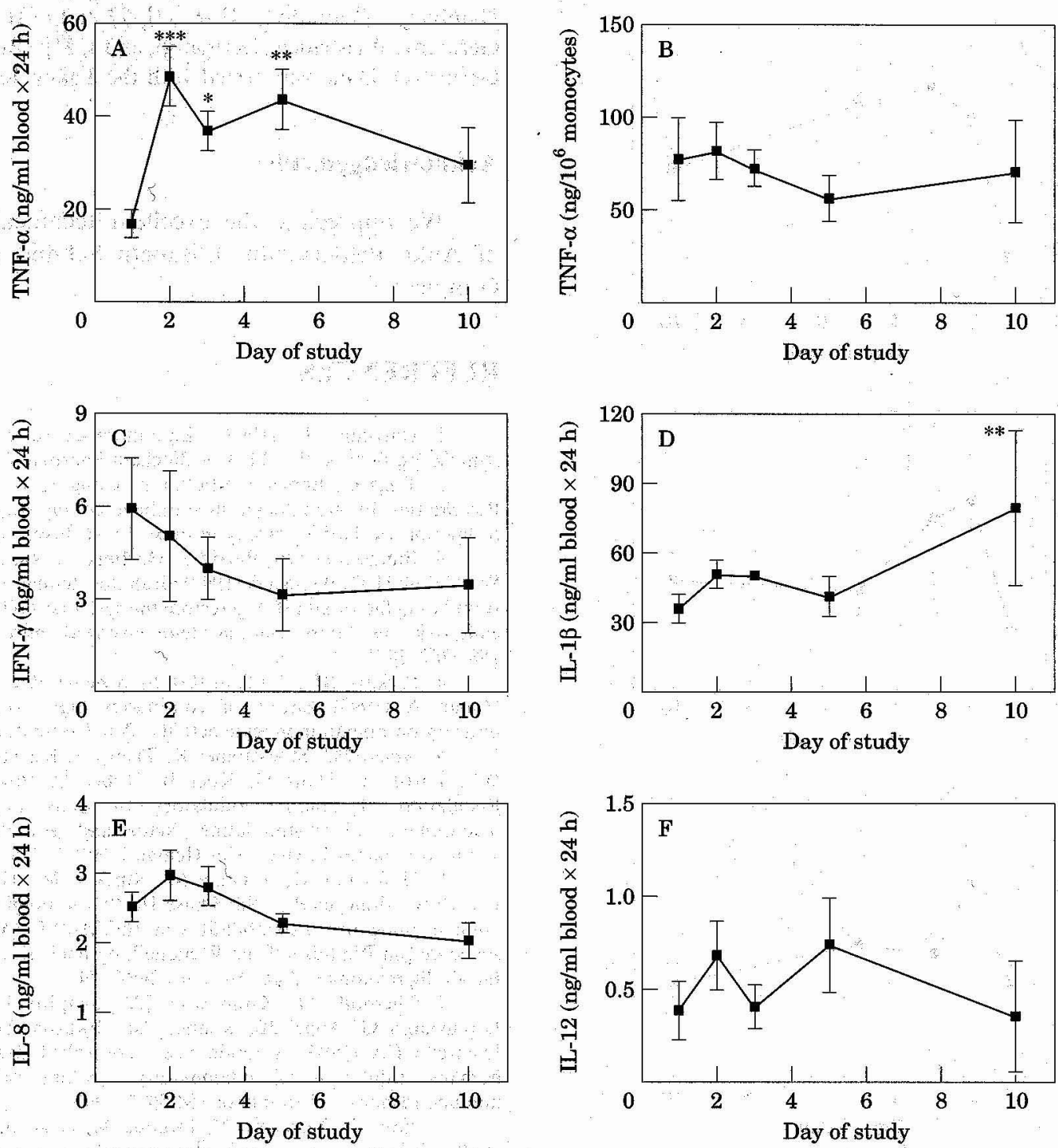

Figure 3. Pro-inflammatory cytokine pattern.

Release of pro-inflammatory cytokines by whole blood of patients who received $1 \mu \mathrm{g} / \mathrm{kg}$ or $2 \mu \mathrm{g} / \mathrm{kg}$ molgramostim per day, incubated with $10 \mu \mathrm{g} / \mathrm{ml}$ LPS for $24 \mathrm{~h}$. The release of TNF- $\alpha$ calculated per monocyte is also shown (B). A, TNF- $\alpha, \mathrm{C}$, IFN- $\gamma ; \mathrm{D}, \mathrm{IL}-1 \beta ; \mathrm{E}, \mathrm{IL}-8 ; \mathrm{F}, \mathrm{IL}-12$.

immunostimulatory property of rhGM-CSF, i.e. its ability to recruit potent granulocytes and monocytes, is already effected at low doses with relatively mild side effects, opening up new potential indications.

\section{MATERIALS AND METHODS}

\section{Study design}

Twenty-three patients of both sexes aged 40 to 85 who had a non-ulcerating basalioma of the face or neck removed by cryosurgery were enrolled into the open-label study. Patients received $2 \mu \mathrm{g} / \mathrm{kg}(n=14)$ or $1 \mu \mathrm{g} / \mathrm{kg}(n=9)$ molgramostim (Leukomax ${ }^{\circledR}$, provided by ESSEX Pharma, Munich, Germany), subcutaneously for 10 days starting on the day of surgery. Blood samples were collected in the mornings on days $1,2,3,5$ and 10 before drug injection. Of the group receiving $2 \mu \mathrm{g} / \mathrm{kg}$ molgramostim, six patients withdrew from the study and six patients were dismissed because their white blood cell count (WBC) rose above $15000 / \mu \mathrm{l}$. In the $1 \mu \mathrm{g} / \mathrm{kg}$ group, three patients were dismissed for this reason.

\section{Laboratory measurements}

Automated differential WBC were performed. Five $\mathrm{ml}$ $20 \%$ whole blood in RPMI 1640 (Biochrom, Berlin, Germany) supplemented with $2 \mathrm{mM}$ glutamine, $100 \mathrm{IU}$ penicillin, $100 \mu \mathrm{g} / \mathrm{ml}$ streptomycin and $2.5 \mathrm{IU}$ heparin (Hoffmann LaRoche, Grenzach-Whylen, Germany) was stimulated with $10 \mu \mathrm{g} / \mathrm{ml}$ LPS from Salmonella abortus equi or $10 \mu \mathrm{g} / \mathrm{ml}$ LTA from Staphylococcus aureus (both Sigma, Deisenhofen, Germany). After $24 \mathrm{~h}$ at $37^{\circ} \mathrm{C}$ vials were shaken 

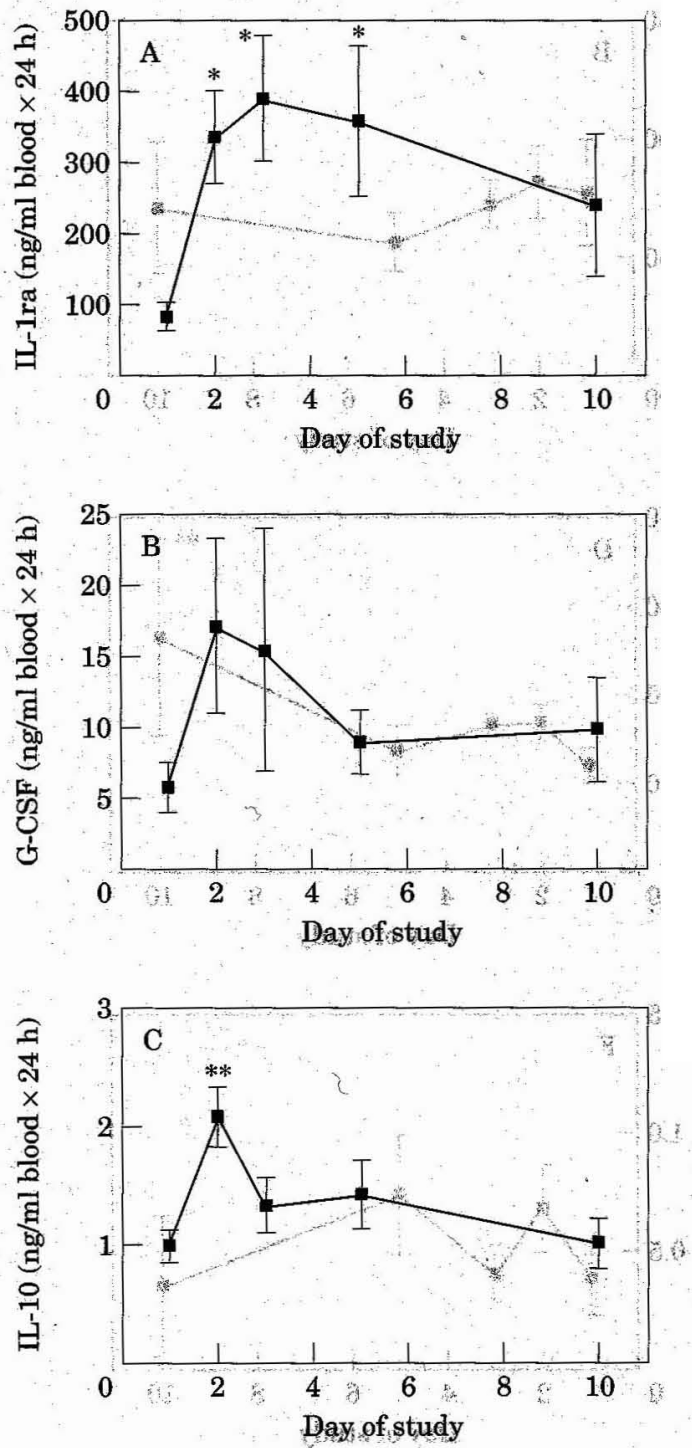

Figure 4. Anti-inflammatory cytokine pattern.

Course of LPS-inducible anti-inflammatory mediators released by whole blood of patients treated with $1 \mu \mathrm{g} / \mathrm{kgg}$ or $2 \mu \mathrm{g} / \mathrm{kg}$ molgramostim per day. A, IL-1ra; B, G-CSF; C, IL-10.

and centrifuged $(300 \times g, 5 \mathrm{~min})$. Cytokines were measured in supernatants by ELISA based on antibody pairs against IL-6, IL-10, TNF- 0 IFN- $\gamma$ and G-CSF (Pharmingen,
Hamburg, Germany), IL-8, IL-12 and IL-1ra (R\&D, Germany, Wiesbaden, Germany), and IL-1 $\beta$ (Biozol, Eching, Germany). Data were tested with the Tukey-Kramer test.

\section{Acknowledgements}

We appreciate the excellent technieal assistance of Anke Biedermann, Elisabeth Schmid and Volker Gimple.

\section{REFERENCES}

1. Hartung $T$ (1999) Immunomodulation by colonystimulating factors. Rev Physiol Biochem Pharmacel 136:1-164.

2. Tiegs G, Barsig J, Matiba B, Uhlig S, Wendel A (1994) Potentiation by granulocyte macrophatge colony-stimulating factor of lipopolysaccharide toxicity in mice. J Clin Invest 93:2616-2622.

3. Bundschuh DS, Barsig J, Hartung T, Randow F, Döcke W-A, Volk H-D, Wendel A (1997) Granulocyte-maerophage colonystimulating factor and IF N-g restore the systemic TNF-a response to endotoxin in lipopolysaccharide-desensitized mice. J Immunol 158:2862-2871.

4. Perkins RC, Vadhan-Raj S, Scheule RK, Hamilton R, Helian A (1993) Effects of continuous high dose rhGM-CSF infusion on human monocyte activity. Am J Hematol 43:279-285.

5. Aman MJ, Stockdreher K, Thews A, Kienast K, Aulitzky WE, Fapber L, Haus U, Koci B, Huber C, Peschel C (1996) Regulation of immunomodulatory functions by granulocytemacrophage colony-stimulating factor and granulocyte colonystimulating factor in vivo. Ann Hematol 73:231-238.

6. Woffmann $\mathrm{K}$, Freitag $\mathbf{M}$, Stücker $\mathrm{M}$, Höxtermann $\mathrm{S}$, Ullich \$, Altmeyer P (1998) Phase IIra "Dose-ranging" Studie zur Untersuchung der Tơferabilität von rhGM-CSF (Molgramostim) sowie dessen Einfluß auf die Wundheilung nach Kryochirurgie des Basalzellkarzinomas. Akt Dermatol 24:67-74.

7. Chernoff AE, Granowitz EV, Shapiro L, Vannier E, Lonnemann G, Angel JB, Kennedy JS, Rabson AR, Wolff SM, Dinarello CA (1995) A randomized, controlled trial of IL-10 in humans. Inhibition of inflammatory cytokine production and immune responses. Immunol 154:5492-5499.

8. Xing Z,Ohlkawara Y, Jordana M, Graham F, Gauldie J (1996) Trânsfer of granulocyte-macrophage colony-stimulating

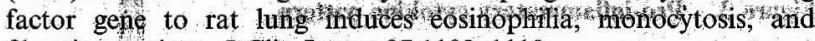
fibrotic reactions. J Clin Invest 97:1102-1110.

9. Wrieger G, Krieba M, Vehmeyer K, Nagel GA, Welte K (1990) Use of telombinant human granulocyte-nacrophage colonystimulating factor in T-lymphocytosis with granulocytopenia. Eur $\mathbf{J}$ Haematol 44:205-206.

10. Xing Z, Gauldie J, Cox G, Baumann H, Jordana M, Lei XF, Achong MKr (1998) IL-6 is an antinflanimatory eytokine required for controlling local or systemic acute inflammatory responses. J Clin Invêst 101:31T-320. 